\title{
Rational Pension Policies ${ }^{\mathrm{a}}$
}

Axel Börsch-SupAn ${ }^{b}$

\section{SUMMARY}

Aim of this keynote is to develop a framework how to approach the design of pension policies as rationally as possible. The first step is to realize and accommodate endogenous adjustments. The second step is to align the root causes of demographic change with corresponding reform steps which include but are not confined by pension reform. The third step is to separate the issues as best as possible to strengthen the political feasibility of reform.

The paper shows that relatively few and moderate reform steps suffice to solve the demographic problem in countries such as Germany and Switzerland. This is in striking contrast to the widespread resistance to reform. We falsify some of the myths, prejudices and misperceptions which make reforms politically so hard to put into place.

a Keynote speech at the Annual Congress 2015 of the Swiss Society for Economics and Statistics on "The Solvency of Pension Systems" Basel, 3 June 2015.

b Munich Center for the Economics of Aging (MEA) at the Max-Planck-Institute for Social Law and Social Policy; Technical University of Munich (TUM); and National Bureau of Economic Research (NBER), Cambridge, Mass. 


\section{Introduction}

In all countries, pension policies stir great controversy and provoke often explosive and highly emotional reactions. Pension reform is called the "third rail" in politics, referring to the high voltage rail in underground transportation (SAFIRE, 2007). Touching it spells trouble. Pension reform attempts have caused violent demonstrations in countries with a strong leftist movement such as France and Greece, but pension reform has also failed in the archetypical capitalist country of the United States, where the last significant reform took place in 1983, followed by 25 years of debate and several commissions without producing a tangible result. Even in this country, Switzerland, which is known for its sober and realistic attitude towards economic issues, pension policies are difficult to enact because voters with many different interests have to be convinced if a new policy should pass the necessary referendum.

Aim of this keynote is to develop a framework how to approach the design of pension policies as rationally as possible. It is an analytical approach for policy designers, not necessarily a communication strategy for policy makers. Hence, the lecture starts with a brief description of the problem to be solved and a macroeconomic analysis of what turns out not to be a problem. The second part, which is the core of the lecture, structures the demographic problem by the various root causes and aligns them with the corresponding reform steps, including pension reform but also much broader policy changes. I will map these reform steps into examples of pension reforms which have already been done across the world.

As it turns out, only relatively few and moderate reform steps are necessary to solve the demographic problem in most countries, including France, Germany, Italy, and this country. The third part then attempts to answer the question: Why is it so hard to solve a problem which could be solved with a few moderate reform steps? This leads us into the field of political economy and the myths, the prejudices and the lack of understanding how the fundamental developments in our aging world work.

\section{Demographic Background}

The demographics of ageing population are well known. Figure 1 depicts the old age dependency ratio (the number of persons aged $65+$ divided by the number of persons aged 20-64) and how it will change from 2010 to 2030 and from 2030 to 2050 . There are two groups of countries: relatively young countries (e.g.: US, 


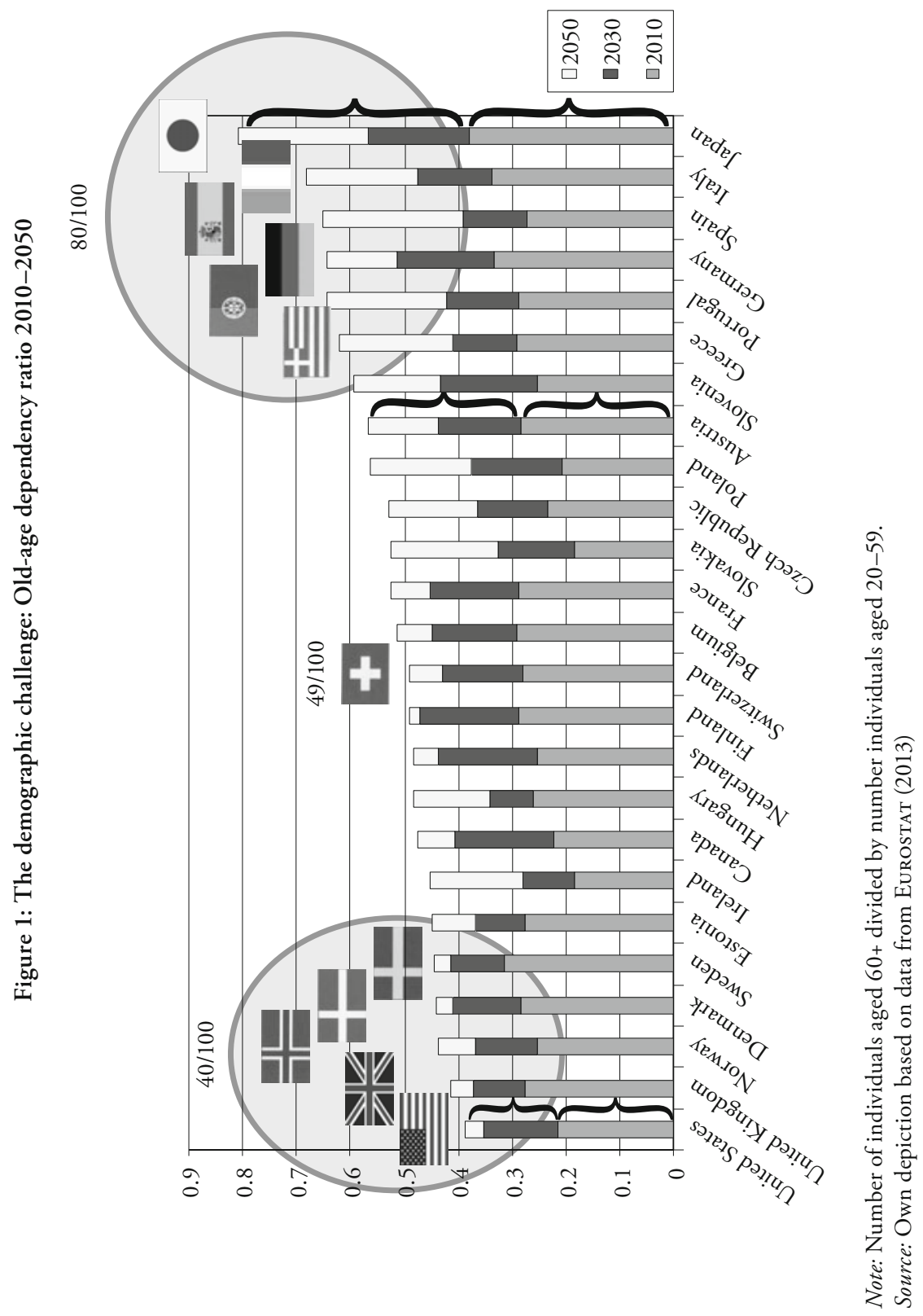


UK, Scandinavia) and relatively old countries (e.g.: Mediterranean countries, Japan, Germany). Switzerland is in between the two groups.

While the levels of dependency are quite different across these countries, the change over the next 15 to 35 years is about the same, an important insight: the dependency ratio will about double. What does this mean? If a burden doubles and has to be divided among two parties - here the young generation and the old generation - then the additional burden is about $40 \%$ for each party. ${ }^{1}$ Translated into pension financing, this means an about $40 \%$ increase of contributions and an about $40 \%$ reduction of benefits. These are serious changes. There is the danger that the benefit cuts will drive some people into poverty and that the increase in contributions will reduce labor supply such that the pension system nevertheless fails to regain solvency. Even worse, both could happen. There is a serious trade-off - or conflict - between the adequacy of pension benefits and the solvency of the pension system.

The situation is even more dangerous because not only the pension system but the entire economy of a deeply aging country will get under pressure. To see this it is helpful to visualize the magnitude of the underlying demographic forces in macroeconomic terms. As a rough first approximation, we do the following hypothetical exercise and very simplistically equate the number of workers with the productive capacity of a country. If this were the case, then economic growth would decline in proportion to the decline of the number of workers per capita of the population. This is shown in Figure 2 for the European Union, the US and Japan.

First, the large swings are noteworthy. They reflect the demography of the baby boom/baby bust transition and its secondary and tertiary effects on the children and grandchildren born by the baby boomers and missing from the baby bust generation. Second, the annual percentage loss in working age individuals per capita of the population would be substantial in some periods, namely up to two percentage points, i.e., about as large as the usual productivity gains. This would bring economic growth more or less to a halt during these periods.

1 Since one minus the square root of two is 0.41 . 
Figure 2: The macroeconomic challenge: Annual percentage loss of workers per population, 2010-2050

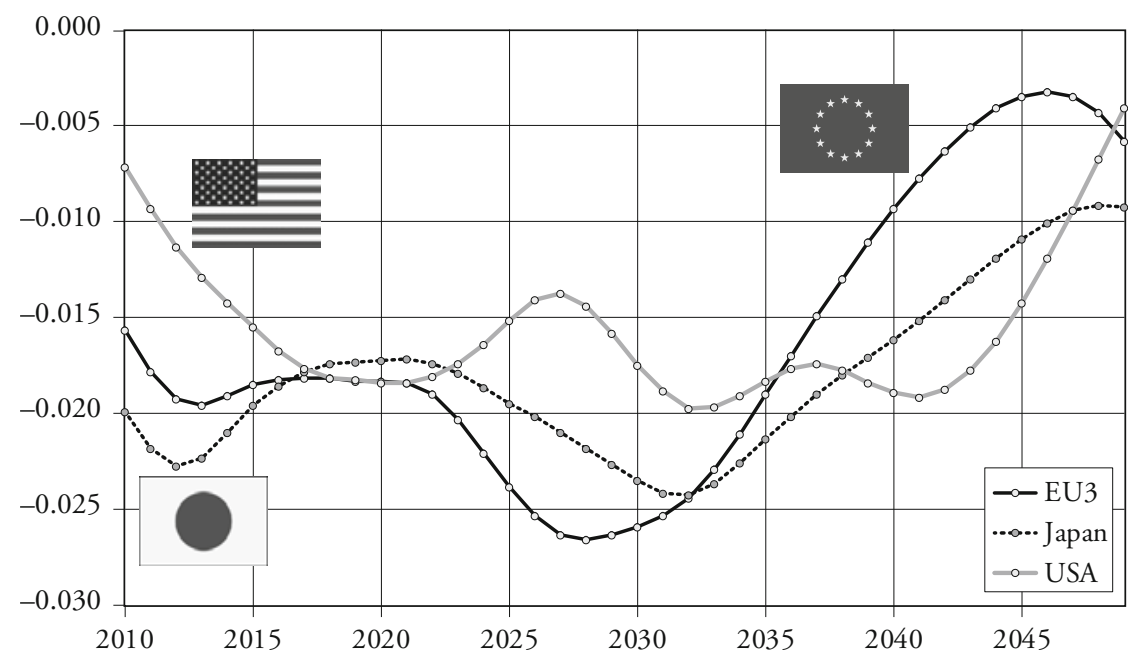

Source: Own depiction based on the data in Eurostat (2013).

\section{The Power of Endogenous Macroeconomic Adjustments}

Fortunately, the bleak picture derived from Figures 1 and 2 will only become reality if nothing else except demography will change. However, this is unlikely to happen for two reasons. First, even in the absence of policy interventions, there will be endogenous macroeconomic adaptations to an aging population. Demography does not translate one to one into economics since there are forces within economics which tend to moderate demographic shocks. This is important for a rational policy approach. Part of the problem will be solved by itself if only market forces will be allowed to work themselves out freely. There is thus less left for structural reform than suggested by the $40 \% / 40 \%$ back-of-the-envelope calculation of the previous section. Second, even given the widespread recent resistance to reform by the populace, we do observe a slow but steady adjustment of policies to an aging world. I will address the endogenous macroeconomic adjustments in this section and the policy adjustments in Section 4.

"Nothing else changing" is impossible in an economy which is aging as dramatically as described by the doubling of the old age dependency ratio. Very fundamentally, dramatic aging will not leave relative prices unchanged. The 
most important price signal will be increasing wages relative to the price of consumption goods since in an aging economy there are more old people and fewer young people, thus also fewer workers per consumer. In addition, wages will increase versus the rate of return of capital because the number of worker will decline faster than the stock of productive capital. ${ }^{2}$ Third, domestic wages in an aging country will increase versus the wages in more youthful countries, since labor will become scarcer in old relative to young countries. ${ }^{3}$ The relative price changes will then change the allocation of labor, capital and consumption both within and between countries.

These endogenous adaptation mechanisms will make the aging problem substantially less severe than the simplistic conclusions from pictures such as Figures 1 and 2 suggest. One cannot directly translate demographics into macroeconomics. More sophisticated economic models are required which describe the substitution between labor and capital within a country and the shift in production from old to young countries, two mechanisms which are of particular importance for Switzerland. These mechanisms are endogenous in the sense that they will happen automatically even without policy interventions at least in a free market situation.

Figure 3 is based on such a macroeconomic model for the combination of France, Germany and Italy, representing the three largest economies of an aging Europe. The model takes the US as the counterpart of a relatively young country. The model is explained in BörsCH-Supan et al. (2014) in more detail; it is a conventional model of overlapping generations augmented by international trade and capital flows and frictions in the labor market typical for the three countries on which it is based. While the model is highly stylized, it is calibrated to reproduce economic growth and international trade of the recent decades. ${ }^{4}$

Figure 3 shows four trajectories. The lowest one is the essence of demographic aging for a macroeconomy, namely the number of workers per capita of the population, usually called the support ratio. It declines by about 20 percent for the average of the three countries between now and 2050. Based on the same demographic projection as Figure 2, this is exactly the same loss of productive capacity which was shown in that figure.

2 Since the stock of productive capital adjusts slowly to the number of workers.

3 Since labor mobility tends to be slow.

4 These models follow the tradition of Auer Bach and KotLikoff (1987). Earlier versions with international exchange are Attanasio et al. (2007), Börsch-Supan et al. (2006) and Fehr et al. (2003). 
Figure 3: Endogenous adaptation mechanisms: support ratio, GDP, GNP and consumption per capita (international diversification: $2005=100 \%$, detrended)

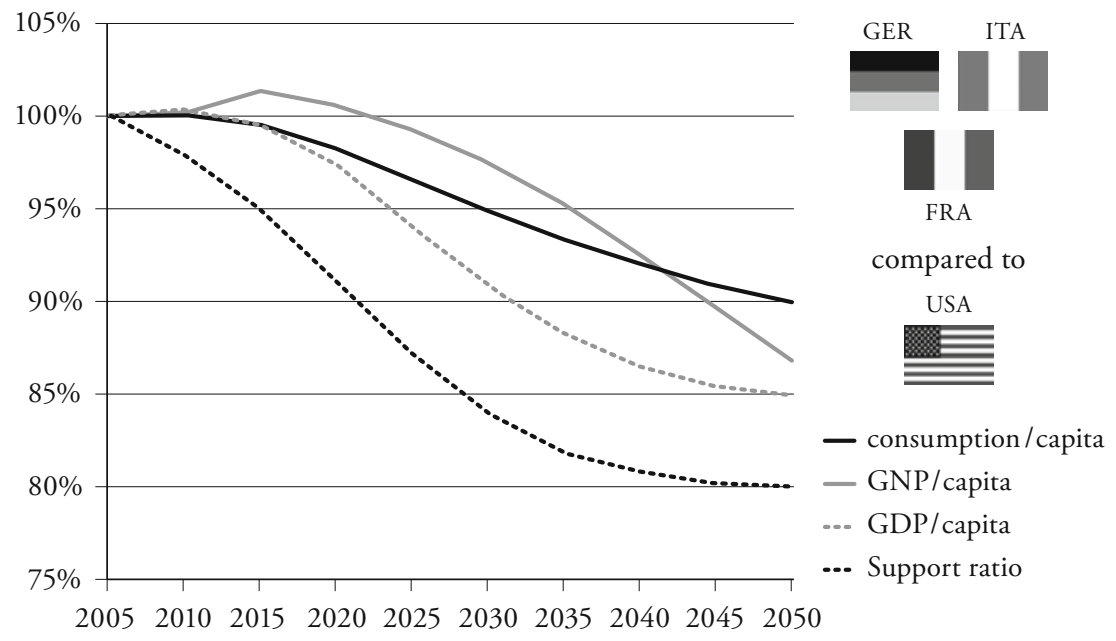

Source: Börsch-Supan et al. (2014).

GDP per capita, however, does not decline as quickly as the support ratio but about 5 percentage points less. This reflects the substitution of labor by capital. Since wages go up because labor becomes scarce in an aging population, and rates of return decline relative to wages, capital intensity will increase. The relative lack of young workers is therefore partially compensated by an increase in the number and sophistication of machines, computers etc. in the production process. This first endogenous mechanism is no surprise to an educated economist; it is, however, quickly ignored in the public discussion. Moreover, its size is substantial, solving about a quarter of the macroeconomic aging problem.

The second beneficial endogenous mechanism is international diversification. Figure 3 shows gross national product (GNP) per capita in addition to gross domestic product (GDP) per capita, i.e. total world income earned by French, German and Italian residents as opposed to total production generated within French, German and Italian borders. Differences between GDP and GNP can get substantial in aging countries because of wage and rate-of-return differences. For aging countries, it is worthwhile to shift production of consumption goods to abroad because labor is scarce in the home country and returns to productive capital are higher abroad. The foreign direct investment creates income for the aging countries. 
GNP per capita will still increase for some while during which the support ratio already is in decline. Afterwards, GNP declines less and at a slower pace than the support ratio. The baby-boom generation will first participate in foreign direct investment and then repatriate the returns. This, in turn, permits to dampen the decline in consumption per capita, the fourth trajectory in Figure 3. While the support ratio declines by about 20 percent until 2050, consumption per capita only declines by about 10 percent during the same time.

Hence, half of the macroeconomic aging problem will actually be solved by endogenous forces - at least if one allows for a significant increase of the capital intensity within the aging country and if one lets capital move freely across borders. This is an important message for public policy and puts purely demographic scenarios in some perspective. On the one hand, as already emphasized, the economic problem is substantially smaller than demography suggests; less has to be done by structural reform. On the other hand, these two conditions (free adjustment of capital intensity and free trade and capital movements) are by no means trivial and often highly political. The first condition requires the installation of more capital intensive production technologies -- but not all unions support this. The second condition requires open borders for capital, goods and services -- but we often observe protests against globalization, e.g. at the G7 summit in Bavaria at the same time as this keynote speech.

\section{The Power of Policy Adjustments}

While about half of the demographic problem can be solved endogenously by macroeconomic adaptation, for the other half one actually has to change the underlying structure of labor markets and pension systems. Figure 4 uses the same macroeconomic model underlying Figure 3 and shows projections of living standards (here: GDP per capita) under various policy scenarios.

Scenario A, the lower of the three trajectories, represents the status quo, i.e. no policy changes. The decline of 15 percentage points corresponds to the scenario which was depicted in Figure 3.

In Scenario B a lot will change and many of the current labor market restrictions in the three countries will be released such as mandatory retirement age in Germany, the 35-hour week in France, and the unavailability of child care for many Italian women who want to work and have children. This is modelled in a very stylized way by imposing the labor market participation rates that are currently observed in Denmark. 
Scenario $\mathrm{C}$ adds a pension reform along the lines enacted in Sweden (PAlmer, 2000). The point of this third scenario is to remove labor supply disincentives which were embedded in the French, German and Italian pension systems (Börsch-Supan, 2000; Gruber and Wise, 2004).

Figure 4: Policy Adaptation Mechanisms: Labor Market, Pension and no Reform

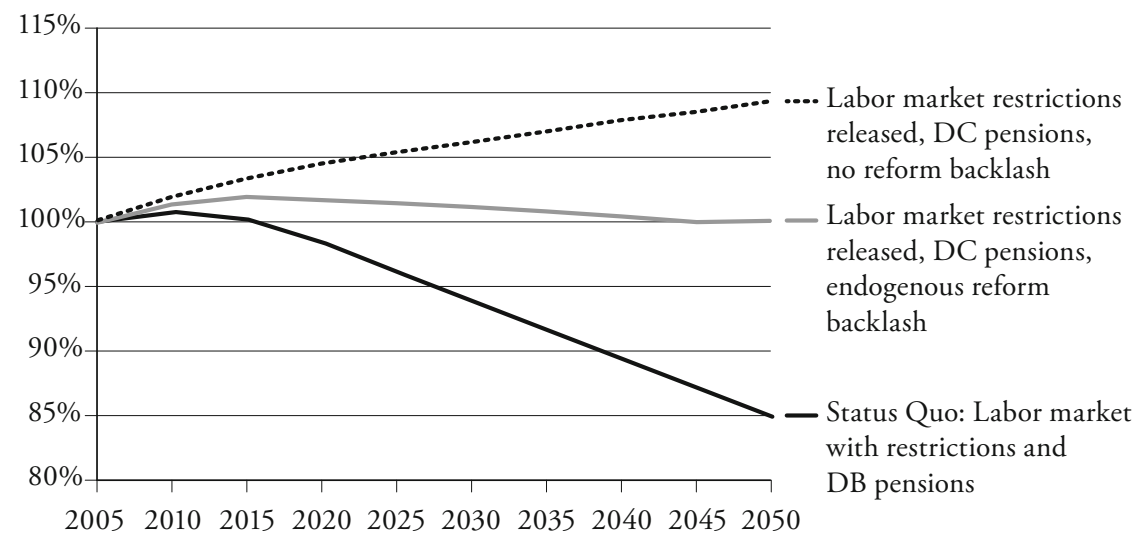

Source: Adapted from BöRsch-Supan et al. (2014).

The main result which can be drawn from this simulation exercise is that policy changes of a similar magnitude as those which have already been enacted in Denmark and Sweden would make a large difference in future living standards. Depending on the depth of reform, living standards may decline, remain constant or increase in spite of population aging. In this sense it is not demography per se which will determine our future economic well-being but the way in which we will be able to react to demographic change by applying the appropriate policy reforms.

To phrase it succinctly: Demography per se is not a problem because there are sufficient endogenous counterbalancing forces (Figure 3) and moderate policy actions (Figure 4) which will compensate for population aging. Making sure that the endogenous forces can actually work and making sure that the policy reforms are actually done is the real problem. This is the aim of the following section. 


\section{A Framework for Rational Pension Policies}

This section employs an analytical approach to reform. I will first identify the root causes of demographic change and map these root causes to possible cures. I will then separate the various reform steps and underlying issues into three distinct layers in order to make pension reform less emotional and more transparent.

\subsection{Three Causes with Three Cures - and One Additional Policy Target}

Demographic change is driven by three very different and largely independent developments. This is depicted in Figure 5 which is based on a demographic projection for the German population. Given three independent causes, one needs at least three different policy instruments to address them. If one has additional policy objectives in mind, such as poverty prevention, one needs even more policy instruments.

The first cause for demographic change is the transition from baby boom to baby bust. This transition occurred in almost all countries in the western world but in different years and with different suddenness. The transition was early and extended in the US; it was particularly sudden and late in Germany. The transition from baby boom to baby bust was a historical event due to World War II. It cannot be undone and the timing of its consequences is fixed and well anticipated.

The second cause for demographic change is the unabated increase in longevity. While statistical offices keep projecting its end, it has not happened yet (OEPpeN and VAUPEL, 2002). Life expectancy increases about 2 years every decade, quite linearly, and is accompanied with an increase in good health at least in Europe so far (Börsch-Supan, 2014, using Eurostat, 2013, data). ${ }^{5}$ It is a root cause for demographic aging but certainly something we do not want to change.

The third cause for demographic change is the secular decline in fertility since the late $19^{\text {th }}$ century. There are large differences across developed countries. The Mediterranean countries and Germany have particularly low fertility rates; Switzerland only slightly higher while France and Sweden have much higher fertility rates not far from the rate necessary for a continuous replacement of the population (about 2.1). The fertility rate of the US is even slightly higher than this. There is some evidence that the fertility rate is U-shaped in income: first declining, then increasing again such as in the US but this evidence is still controversial

5 This is different in parts of the US population, see the change from FreEdman et al. (2004) to Freedman et al. (2013). 


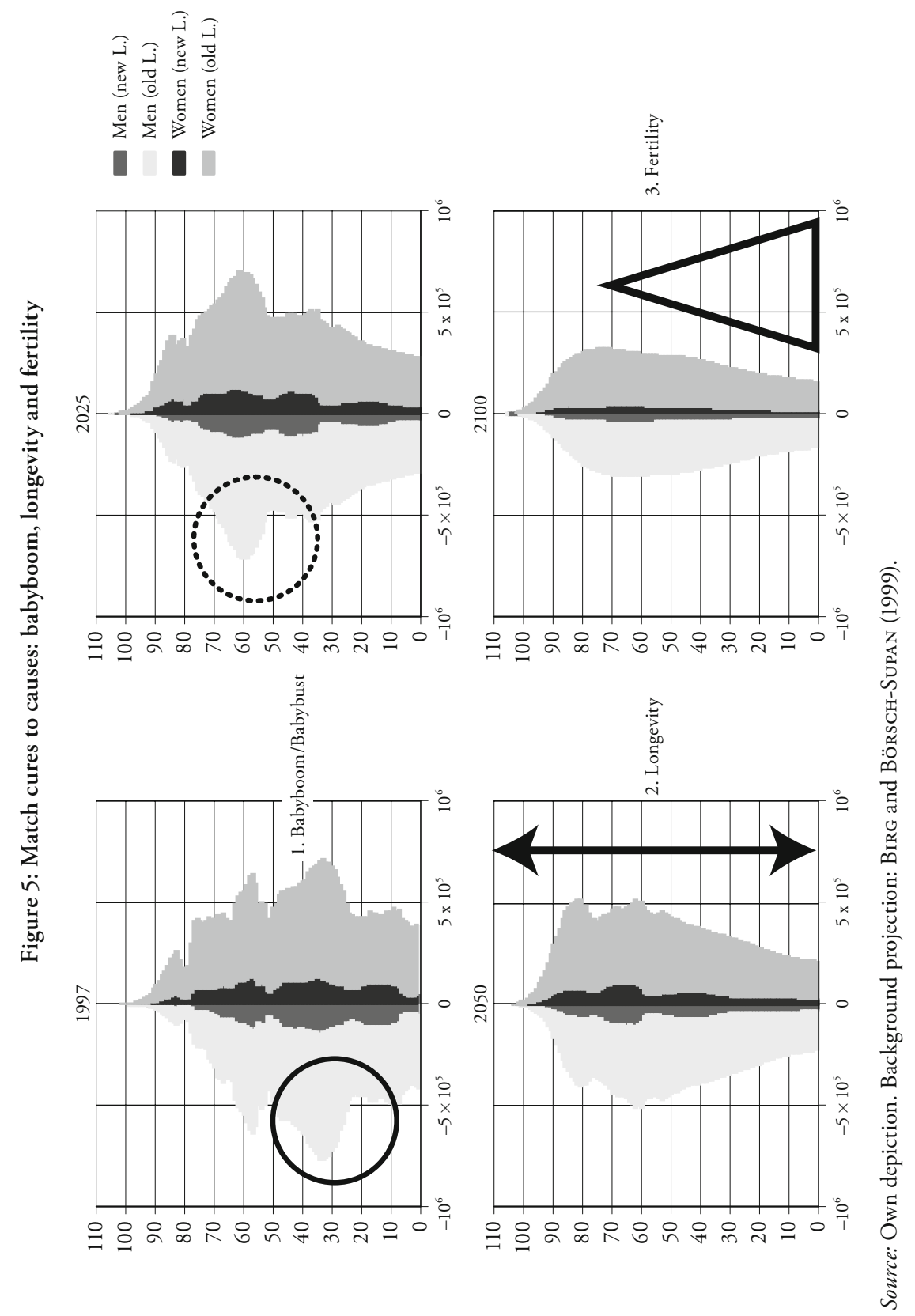


(Myrskylä et al., 2009). Even if there were to be another baby boom within the next 10 years, this would not help the pension system until about 25 years later since children need to be educated in order to reach full productivity.

These three root causes for demographic change are essentially independent from each other and require different policy responses. The baby boom/baby bust transition is a transitory problem. The traditional way to resolve transitory problems is smoothing by saving in anticipation, then taking up loans when the financial pressure is large, and repaying the loans when the pressure subsides. In terms of pensions, this is the key reason to pre-fund a larger share of pension benefits rather than to finance them pay-as-you-go. Genuine pre-funding requires investment in productive capital, not government loans since these are solely claims on future taxes, thus form themselves a pay-as-you-go system (VALDÉsPrieto, 2000). In many countries, including Switzerland, pension funds have invested mainly in government bonds and therefore fail to contribute to a genuine reduction of the future aging burden.

Fiscal consolidation fulfills the same purpose as pre-funding. Getting rid of debts now increases the potential of raising debt in the future when the demographic pressure will be highest. The current high debt ratios of many countries in the aftermath of the financial crisis will add to the fiscal pressures in about 10-20 years; fiscal consolidation is thus a very important preparation for the peak of population aging.

The policy answer to the second root cause -- longevity -- is obvious: a society which lives longer has to work longer such that the ratio of years spent with leisure and education to years spent working remains roughly constant. I will return to this issue later.

The secular decline in fertility has proven to be the hardest problem to solve. Germany may be a sobering example. Over the last 40 years; Germany has experimented with all kind of family policies, some proposed by the political right, some by the political left, in an attempt to increase fertility. The fertility rate, however, has remained remarkably stable - and low.

One therefore may want to fundamentally change the point of view here. If one appears to fail changing the quantity, one may want to try to increase the quality of children, e.g., by providing better education and then investing more in health care to keep them healthy and productive.

In addition to these three distinct policies which match the three root causes of demographic change, further policies may be needed to achieve distributional goals. This is particularly important because all three reform elements have distributional side effects. Prefunding means to save more and consume less which is harder for the less well to do. Later retirement ages are hard for those in ill 
health which again tend to be poorer individuals. Better education and health care cost money as well which has to be raised by higher taxes. We therefore end up with four basic policy responses which make up the tool box for rational pension reform: some extent of pre-funding, later retirement, more investments into education and health, and re-distribution.

\subsection{Separating Issues}

One of the problems in the political discussion is that it tends to mix up policies and arguments which are actually separate issues. This makes a stringent argumentation often very hard. This is partly because people do not understand the system and therefore do not distinguish various causes or confuse causes with consequences. Even worse, this lack of knowledge and the complexity of the system is sometimes demagogically exploited to force a normative point to the audience. Some argue that the lack of transparency and the fragmentation of a pension system in many countries is not an unfortunate side effect but purposefully engineered since it permits hiding special interests in the political process (see the example of Greece, Börsch-Supan and Tinios, 2001).

A rational policy approach requires separating issues which are independent from each other or can be solved independently by using the appropriate sequence of reform steps. A good example is to cleanly separate the issue of poverty prevention from the issue of sustainability (or solvency in the parlance of this conference). To make an insolvent pension system sustainable, benefit cuts are unavoidable. This argument, however, tends to be easily dismissed in political discussions with the counterargument that this will necessarily increase old-age poverty. This is wrong. One can solve the sustainability problem for 80 or 90 percent of the population and then, separately, take care of the other 10 or 20 percent who are indeed in danger of old-age poverty. This can be achieved by using separate instruments (e.g., benefit cuts in proportion to population aging plus a meanstested base pension with benefits independent of population aging).

Separation does not mean that the quantity of one reform element is necessarily independent from the quantities involved in all other reform element. E.g., deeper cuts in the general level of pension benefits require a larger extent of poverty prevention; better education induces higher productivity which may lessen the need for benefit cuts, etc. Just the opposite: the existence of other reform elements allows one to design one reform separately from other considerations. E.g., one can design a pay-as-you-go system which is responsive to population aging and remains solvent in the aggregate separately from poverty considerations because one knows that another reform element will take care of old-age poverty. 
Figure 6: Rational Pension Reform

1. Prevent poverty

\section{Means-tested base pension!}

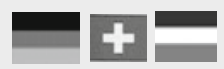

2. Solve sustainability issues for the "normal" worker

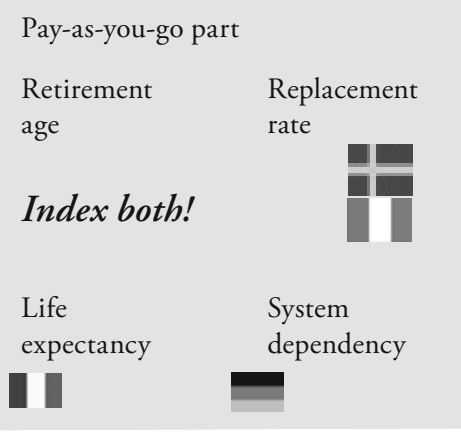

3. The long-term issue of low fertility

\section{Education!}

Fully-funded part

Occupational Individual
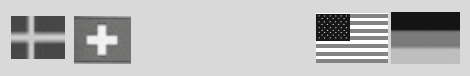

Solve governance problems!

Source: Own depiction.

Figure 6 separates the four basic policy responses identified in the previous subsection into three layers. They are described in this subsection in the abstract; the next subsection will provide some country-specific examples.

The first layer of reform is to make sure that a system is in place which takes care of old-age poverty before any other reform dimension is tackled with, so one has the freedom to design the other reform dimensions in an appropriate way. While one may debate the appropriate level of a means-tested base pension, its introduction as a "zero pillar" (Holzmann and Hinz, 2005) is conceptually easy and has been done in many countries quite successfully as the OECD data on old-age poverty reveals (OECD, 2013).

The second layer of reforms addresses the solvency of the pension system as a whole, seen through the eyes of the median individual or "normal" worker. There are many policy measures in this layer and they differ by addressing the payas-you-go (PAYG) part and the fully funded (FF) part of a typical multi-pillar pension system. Population aging forces the PAYG system to cut down life-time benefits in order to keep solvent without suffocating increases in life-time contributions. Life-time benefits have two dimensions: the level of annual benefits 
and the duration during which benefits are being paid which is determined by the retirement age. We argue that establishing an indexation rule minimizes the problems of the political process for both dimensions. So the level of annual benefits should be indexed to the demographic pressures on the pension system, and the duration of retirement benefits should be indexed to the expected duration of life. There are many ways to do this in practice. They will be discussed below along several country examples.

While fully funded systems are, by definition, always solvent with respect to demography, there is nevertheless need for reform. We observe breakdowns of private and public pension funds, very low returns to the invested contributions and similar problems which may be summarized as governance failures. Many of these issues are related to poor transparency, and they are, unfortunately, not confined to individual accounts and occupational pension schemes but also include public provident funds (Palacios and Pallarès-Miralles, 2000). Note that these issues can and should be discussed quite separately from the issues of poverty prevention and PAYG reform.

This holds even more for the third layer of necessary reform steps: offsetting the lower number of children by their higher productivity through better education and a consistent approach to life-long preventive health care.

\subsection{Country Examples}

Since pension policies have been developed over time in different cultural, economic and historical circumstances, examples for policies in each layer of Figure 6 differ from country to country.

Regarding the first layer of reforms, the introduction of a means-tested base pension was actually the first step of the pension reform sequence in Germany from 2001 to 2007. It turned out to be politically very helpful that this thorny issue was out of the way before the next reform steps - introduction of Riester pensions, indexing the PAYG system and increasing retirement age - were legislated, see Börsch-Supan and Wilke (2003).

In turn, the Swiss and Dutch first pillars combine poverty prevention with the base pension for a "normal worker" in the PAYG part of their multi-pillar pension systems. This appears to make reform harder for each of the addressees. Since it is a combined pillar, reducing it in order to solve the sustainability problem cannot be separated from creating higher old-age poverty.

Indexing to life expectancy, pioneered by Norway, has now been successfully introduced in parts of the French system. Note that increasing the retirement age by the same amount as life expectancy increases amounts to over indexing. 
The essential point is to keep the proportions in life constant. Roughly speaking, working life lasts twice as long as life in retirement. Hence, if we were to live 3 years longer, then it would be perfectly fine to enjoy one more year in retirement but this year has to be financed by two more years of working. This rule has been implemented in Germany in a long gradual transition from 2007 through 2029.

Indexing benefits to the system dependency ratio is a way to preserve the "defined benefit" character of a PAYG pension system at the same time as it is shrinking in order to make it sustainable. This was the idea of the so called "sustainability factor" in Germany (Kommission, 2003). It indexes the replacement rate with respect to the number of recipients of benefits from the pension system, divided by the number of contributors to the pension system who finance these benefits. Such an indexation system creates an automatically stabilizing system which, if consistently applied, will be always solvent.

There are more elegant ways to introduce both indexation mechanisms in one stroke. A good example was the introduction of a notional defined contribution (NDC) system in Sweden and Italy after several parametric reforms failed (Palmer, 2000; Holzmann and Palmer, 2003; Franco and Sator, 2003). It is interesting to observe that from a purely economic point of view, the "sustainability factor" in Germany will roughly create the same path of future benefits and contributions as the Swedish NDC system does (Börsch-Supan, 2005). Politically, however, a Swedish style reform was unfeasible in Germany because a NDC system smelled too much like a fully funded system which is distrusted by Germans. This is a good example why pension reform is so country specific. Rational pension reform has to take such irrationalities into account. In addition, governance may be easier in a small country like Sweden where social control is tight than in a large country like Germany.

This may also be the reason why the occupational funded systems are working reasonably well in Sweden and Switzerland. Larger countries, such as Germany and the US, have relied more on individual account systems. In Germany, they have produced a very large range of rates of return, see GASCHE et al. (2013). This study emphasizes the lack of transparency of the account information and computes life-time cost factors. Some plans have very low costs, less than $2 \%$ of lifetime contributions, but there are other plans in which administrative costs, including marketing and profits, make up for more than $80 \%$ of life-time contributions.

Discussing the third layer of reforms (improving education and preventive health care) along country-specific examples would require a lecture by itself. Based on international comparisons such as PISA, TIMSS and PIAAC, countries like Germany and Switzerland fair ok in education but not top. The small Asian countries, e.g. Taiwan, are performing much better according to these studies. 


\section{Perceived Obstacles to Rational Pension Policies}

Sections 3 and 4 have shown that relatively few and moderate reform steps are necessary to "solve" the demographic problem in countries such as France, Germany, Italy, and Switzerland. Section 5 has shown that there exists a well-defined structure how to think about pension reform and how to separate the various issues and problems underlying pension reform. Moreover, there exist a lot of examples how specific countries translated the general principles into separate building blocks of pension reform which can be recombined to fit another country's preferences and restrictions.

Then why is it so hard to solve a problem which could be solved with a few moderate and well-defined reform steps? This leads us into the field of political economy, the lack of understanding how developments in our aging world actually work, and the many myths and prejudices which make a rational pension policy so hard (Galasso, 2007; Boeri et al., 2002) and often produce timeinconsistent policy paths (Kydland and Prescott, 1977). These problems are much more general and fundamental than applicable only to pension reform (Rowe et al., 2009). We will only sketch these here and refer to BöRsCH-Supan (2014) for details.

Many people share the misconception that health is declining quickly after age 60 such that most people cannot work anymore at the later retirement ages currently under discussion. This is not true for the majority of the population. Health declines very slowly between age 60 and 70 , and the variation of health within each birth cohort is much larger than the difference of the average health between age 60 and age 70 (Avendano et al., 2005). This is therefore another example why separating issues is so important: declining health does not set limits to work for most of the population - but it does so for a substantial minority. Hence, declining health is not an obstacle to increasing the retirement age in general. However, accompanying policies are necessary to help the minority of individuals who suffer from work disability.

A second prejudice concerns productivity. Many claim that it decreases with age such that it does not pay to keep older workers in the company. While it is correct that physical and cognitive performance peaks at relatively young ages, experience, management and networking abilities peak much later and show no decline at ages relevant for employment. Taken together, productivity stays relatively flat over the relevant age range. There is no evidence that productivity declines in normal production processes; neither in services nor in the manufacturing industry (Malmberg et al., 2008; Göbel and Zwick, 2009; BörschSupAn and Weiss, 2013). 
Then there is the wide-spread myth that if one creates more jobs for one group of the population then there are fewer jobs left for all other groups. This "lump of labor fallacy" is applied to old workers, immigrants or women, taking jobs from the young, the natives or men. It may apply for single sectors where output is restricted but grossly false for an entire economy which can grow and create additional jobs. Increasing the retirement age actually helps younger workers since it reduces their tax and contribution burden which would otherwise have to finance costly early retirement (see the country studies in GRUBER and WISE, 2010).

Finally there is the hope that retirement is bliss after an arduous working life. Indeed, retirement tends to improve health for those in stressful and physically demanding jobs. It has, however, also negative side effects, especially on cognition; e.g., Inactivity leads to a faster decline of memory functions (ADAM et al., 2007; Rohwedder and Willis, 2010; Behnke, 2012; Coe et al., 2012; Mazzonna and Peracchi, 2012; Börsch-Supan and Schuth, 2014). Hence, early retirement is more of a two-sided sword than most people are aware of.

\section{Conclusions}

The experience collected from pension reforms since the mid-1980s forms a body of knowledge from which one can distill a rational and effective multi-dimensional strategy for pension reform. Its main elements are:

- to index the retirement age and the level of pay-as-you-go benefits in order to keep the proportions of life and the proportion between generations intact,

- to introduce some extent of pre-funding in order to reduce the peak burden of aging,

- to make sure that old-age poverty is prevented by a base pension which is insulated from demographic changes, and

- to improve education and preventive health in order to compensate for low fertility.

These building blocks can be recombined to fit each country's preferences and restrictions.

Not all problems have to be solved by active reform. There are endogenous macroeconomic adjustments which -- if left to work freely -- will reduce the incisiveness of discretionary reform. The most important mechanisms are substitution of labor by capital and international diversification. The strategy of a combination of active pension reform steps and endogenous macroeconomic 
adjustments works even in "Old Europe" since there is - in theory - sufficient labor supply and saving capacity to offset aging in Europe. It only has to be mobilized.

The resistance to reform in many countries appears to be rooted in strong prejudices about aging which are contradicted by evidence. Health at older ages is actually good and getting better for most individuals; productivity in standard jobs is essentially independent of age; the employment of older workers actually strengthens the job chances of the young rather than reducing them; and early retirement is not only a blissful salvation from work but also entails negative side effects, especially on cognition.

Hence, not demography is our destiny but our ability to reform, to let the macroeconomic adjustments work themselves out, and to lay the myths and prejudices about old age to rest.

\section{References}

Adam, S., E. Bonsang, S. Germain, and S. Perelman (2007), "Retirement and Cognitive Reserve: A Stochastic Frontier Approach Applied to Survey Data", CREPP working papers, 2007(04), HEC-ULg.

Attanasio, O.P., S. Kitao, and G.L. Violante (2007), "Global Demographic Trends and Social Security Reform”, Journal of Monetary Economics, 57(1), pp. 144-198.

Auerbach, A.J., and L.J. Kotlikoff (1987), Dynamic Fiscal Policy, Cambridge, MA: Cambridge University Press.

Avendano, M., A.R. Aro, and J. Mackenbach (2005), "Socio-Economic Disparities in Physical Health in 10 European Countries", in Health, Ageing and Retirement in Europe - First Results from the Survey of Health, Ageing, and Retirement in Europe, A. Börsch-Supan, A. Brugiavini, H. Jürges, J. Mackenbach, J. Siegrist, and G. Weber (eds.), MEA, Mannheim.

Benncke, S. (2012), "Does Retirement Trigger Ill Health?”, Health Economics, 21(3), pp. 282-300.

Boeri, T., A. Börsch-Supan, and G. Tabellini (2002), "Would You Like to Reform the Pension System? The Opinions of European Citizens", American Economic Review 92, pp.396-401.

Börsch-Supan, A., and M. Schuth (2014), "Early Retirement, Mental Health, and Social Neworks, in Discoveries in the Economics of Aging, D.A. Wise (ed.), pp. 225-254, Chicago: The University of Chicago Press. 
Börsch-Supan, A., and P. Tinios, (2001), "The Greek Pension System: Strategic Framework for Reform", in Greece's Economic Performance and Prospects, R.C. Bryant, N.C. Garganas, and G.S. Tavlas (eds.), pp.361-451, Athens: Bank of Greece and The Brooking Institution.

Börsch-Supan, A. (2000), "Incentive Effects of Social Security on Labor Force Participation: Evidence in Germany and Across Europe", Journal of Public Economics, 78, pp. 25-49.

Börsch-Supan, A. (2005), "From Traditional DB to Notional DC Systems: The Pension Reform Process in Sweden, Italy, and Germany", Journal of the European Economic Association, Vol.3(2-3), April-May 2005, pp.458-465.

Börsch-Supan, A. (2013), "Myths, Scientific Evidence and Economic Policy in an Aging World", Journal of the Economics of Ageing, 1-2, pp.3-15.

Börsch-Supan, A., and C.B. Wilke (2003), "The German Social Security System: How It Was and How It Will Be”, NBER Working Paper No. 10525, Cambridge, Mass.

Börsch-Supan, A., and M. Weiss (2013), "Productivity and Age: Evidence from Work Teams at the Assembly Line", ROA Research Memorandum, 2013(9), Maastricht University.

Börsch-Supan, A., A. Ludwig, and J. Winter (2006), "Aging, Pension Reform, and Capital Flows: A Multi-Country Simulation Model”, Economica, 73, pp. 625-658.

Börsch-Supan, A., K. Härtl, and A. Ludwig (2014), "Aging in Europe: Reforms, International Diversification, and Behavioral Reactions", American Economic Review P\&P, 104(5), pp. 224-229.

Coe, N.B., H.M. von Gaudecker, M. Lindeboom, and J. Maurer (2012), "The Effect of Retirement on Cognitive Functioning", Health Economics 21(8), pp. 913-927.

Eurostat (2013), http://ec.europa.eu/eurostat/ (online data code: hlth_hlye).

Fehr, H., S. Joкisch, and L. Котlikoff (2003), “The Developed World's Demographic Transition: The Roles of Capital Flows, Immigration, and Policy”, Working Paper No. 10096, National Bureau of Economic Research (NBER).

Franco, D., and N. Sartor (2003), "Notional Defined Contribution in Italy: Unsatisfactory Present, Uncertain Future", Mimeo, Bank of Italy.

Freedman, V.A., E.M. Crimmins, R.F. Schoeni, B. Spillman, H. Aykan, E. Kramarow et al. (2004), "Resolving Inconsistencies in Old-Age Disability Trends: Report from a Technical Working Group", Demography, 41(3), pp. 417-441. 
Freedman, V., B. Spillman, P. Andreski, J.C. Cornman, E. Crimmins, E. Kramarow et al. (2013), "Trends in Late-Life Activity Limitations: An Update from 5 National Surveys", Demography, 50(2), pp. 661-671.

Galasso, V. (2007), The Political Future of Social Security in Aging Societies, Cambridge, MA: MIT Press.

Gasche, M., T. Bucher-Koenen, M. Haupt, and S. Angstmann (2013), „Die Kosten der Riester-Rente im Vergleich“, MEA-Discussion Paper 04-2013, München.

Göвel, C., and T. Zwick (2009), „Age and Productivity - Evidence from Linked Employer Employee Data", ZEW Discussion Paper, 9(20), Zentrum für Europäische Wirtschaftsforschung.

Gruber, J., and D.A. Wise (eds.) (2004), Social Security Programs and Retirement around the World: Micro Estimation, Chicago: The University of Chicago Press.

Gruber, J., and D.A. Wise (eds.) (2010), Social Security Programs and Retirement around the World: Youth Employment, Chicago: The University of Chicago Press.

Holzmann, R., and E. Palmer (2005), Pension Reform - Issues and Prospects for Non-Financial Defined Contribution (NDC) Schemes, Washington D.C.: World Bank.

Holzmann, R., and R. Hinz (2005), Old-Age Income Support in the 21st Century: The World Bank's Perspective on Pension Systems and Reform, Washington, D.C.: The World Bank.

Kommission für die Nachhaltigkeit in der Finanzierung der SoziaLen Sicherungssysteme (2003), Abschlussbericht. Bundesministerium für Gesundheit und Soziale Sicherheit, Berlin, http://www.bmgs.bund.de/deu/ $\mathrm{gra} / \mathrm{themen} / \mathrm{sicherheit/kommission/index.cfm.}$

Kydland, F., and E. Prescott (1977), "Rules Rather than Discretion: The Inconsistency of Optimal Plans", Journal of Political Economy, 85, pp.473-490.

Malmberg, B., T. Lindh, and M. Halvarsson (2008), "Productivity Consequences at the Plant Level of Work-Force Ageing: Stagnation or a Horndal Effect?" Population and Development Review, 34, pp. 238-256.

Mazzonna, F., and F. Peracchi (2012), "Aging, Cognitive Abilities and Retirement”, European Economic Review, 56(4), pp.691-710.

Myrskylä, M, H.P. Kohler, and F. Billari (2009), "Advances in Development Reverse Fertility Declines”, Nature, 460 (7256), pp.741-743.

OECD (2013), Pensions at a Glance, OECD, Paris.

Oeppen, J., and J. Vaupel (2002), "Enhanced: Broken Limits to Life Expectancy”, Science 296 (5570), pp. 1029-1031. 
Palacios, R., and M. Pallarès-Miralles (2000), "International Patterns of Pension Provision", Social Protection Discussion Paper Series No.0009, Washington, D.C.: The World Bank.

Palmer, E. (2000), "The Swedish Pension Reform Model: Framework and Issues", Social Protection Discussion Paper No. 12, Washington, D.C.: The World Bank.

Rohwedder, S., and R.J. Willis (2010), "Mental retirement", Journal of Economic Perspectives, 24(1), pp. 119-138.

Rowe, J.W., L.F. Berkman, R. Binstock, A. Börsch-Supan, J. Cacioppo, L. Carstensen et al. (2009), "Facts and Fictions about an Aging America", Contexts, 8(4), pp. 16-21.

Safire, W. (2007), "On Language: Third Rail", The New York Times, http:// www.nytimes.com/2007/02/18/magazine/18wwlnsafire.t.html, retrieved 8 September 2015.

Valdés-Prieto, S. (2000), "The Financial Stability of Notional Account Pensions," Scandinavian Journal of Economics. 